\title{
Colonization of the Residues of Diverse Plant Species by Gibberella zeae and Their Contribution to Fusarium Head Blight Inoculum
}

\author{
S. A. Pereyra and R. Dill-Macky, Department of Plant Pathology, University of Minnesota, St. Paul, MN 55108
}

\begin{abstract}
Pereyra, S. A., and Dill-Macky, R. 2008. Colonization of the residues of diverse plant species by Gibberella zeae and their contribution to Fusarium head blight inoculum. Plant Dis. 92:800-807.

The presence of Fusarium spp. was examined in the residues of wheat, barley, corn, sunflower, pasture, and gramineous weed species common in wheat and barley cropping systems collected from no-tillage and reduced-tillage plots from February 2001 to March 2003 in Uruguay. Gibberella zeae was recovered from residues of wheat, barley, corn, sunflower, fescue, and the gramineous weeds Digitaria sanguinalis, Setaria spp., Lolium multiflorum, and Cynodon dactylon, except from birdsfoot trefoil or white clover. Of the Fusarium spp. obtained, G. zeae was the most frequently recovered from wheat and barley residues, while other species were more common in other crops. G. zeae declined over time in all residues examined. Wheat and barley residues produced more ascospores of $G$. zeae than corn or other gramineous residues. Sunflower residue did not support ascospore production, indicating that it probably did not contribute to primary inoculum. Wheat and barley residues supported G. zeae colonization longer in notill than in reduced-tillage production systems and, thus, may represent major contributors to Fusarium head blight (FHB) inoculum in Uruguay. The presence of G. zeae in the gramineous components of pastures, weed species, and sunflower should be considered when implementing control strategies for FHB.
\end{abstract}

Fusarium head blight (FHB) is a devastating disease of wheat and barley in the southern cone of South America. FHB represents one of the main constraints for wheat and barley production in Uruguay, where moderate to severe outbreaks have occurred in 1 of every 2 years over the past decade $(9,30,31)$. Epidemics have caused extensive damage through direct losses in grain yield and quality, particularly because of the presence of mycotoxins such as deoxynivalenol (DON) in harvested grain.

The main pathogen associated with FHB in Uruguay is Gibberella zeae (Schwein.) Petch (anamorph, Fusarium graminearum Schwabe) $(2,3,33,35)$. G. zeae is capable of surviving saprophytically on host residues including wheat, barley, corn, sorghum, and oat; grasses of the genera Agropyron, Agrostis, Andropogon, Botriochloa, Bromus, Cenchrus, Cortaderia, Digitaria, Echinochloa, Lolium, Panicum, Paspalum, Pennisetum, Poa, and Setaria; and numerous nongramineous species $(1,8,11-$ $13,15,32,36,40)$.

Corresponding author: R. Dill-Macky

E-mail: ruthdm@umn.edu

Current address of S. A. Pereyra: Instituto Nacional de Investigación Agropecuaria (National Institute for Agricultural Research), INIA La Estanzuela,

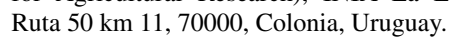

Accepted for publication 14 January 2008

doi:10.1094/PDIS-92-5-0800

(c) 2008 The American Phytopathological Society
Wheat, barley, and corn residues have long been regarded as the major sources of primary inoculum $(39,40,44)$ in FHB epidemics. The quantity of initial inoculum produced, principally ascospores $(20,36)$, is reported to be directly related to the amount of colonized host residues at the soil surface $(10,18,32)$. The importance of primary inoculum in FHB development, which is considered a monocyclic disease, justifies the use of cultural management practices, including rotation with nonhosts or the destruction of crop residues $(16,17,22,43)$, for disease control.

The increased use of soil conservation practices in Uruguay since $1992(21,23)$ and the diversity in pasture species, common weeds, and crops prevalent in mixed production systems (agriculture and livestock production) raise questions about the ecology of G. zeae and the epidemiology of FHB. Establishing effective strategies to manage G. zeae-infested residues requires an understanding of the contribution of these residues to the survival and production of $G$. zeae inoculum. Studies also are needed to identify agronomic practices that may aid in reducing the inoculum pressure from $G$. zeae in Uruguayan production systems.

The objectives of this study were to quantify $G$. zeae survival and inoculum production on a range of gramineous and nongramineous species common in Uruguayan production systems.

\section{MATERIALS AND METHODS}

Experimental site. Experimental plots were established in 1996 at a field site at
INIA La Estanzuela (INIA, National Institute for Agricultural Research, Uruguay) on a clay-loam soil (organic matter 2.1 to $4 \%$; pH 6.2 to $7.0 ; \mathrm{Al}<0.1$ meq/100 g; P > $5 \mathrm{ppm})$. Treatments consisted of combinations of crop rotation and tillage practices. The experiment was a randomized complete block design (RCBD) with three replicates. The two crop rotations examined were continuous agriculture (oatscorn/barley-sunflower/wheat) and a croppasture rotation (oats-corn/barley-sunflower/wheat $/ 3$ years of pasture). Pasture was a mixture comprising fescue (Festuca arundinacea L.), white clover (Trifolium repens L.), and birdsfoot trefoil (Lotus corniculatus L.). The tillage treatments were reduced tillage and no-till. Reduced tillage consisted of vertical tillage with a chisel plow or eccentric disc. No-till plots were not cultivated and were seeded with a direct drill (model 750; Deere and Company, Moline, IL).

Oat crops were planted on 11 April 2001 and 26 April 2002 and grazed by sheep to ground level at stem elongation (Zadoks growth stage [GS] 31 to 32 ; 46) on 10 July 2001 and 21 July 2002, leaving almost no residue. The other winter crops (wheat and barley) were planted on 6 July 1999, 30 June 2000, 4 July 2001, and 22 June 2002 and harvested at maturity (16 December 1999, 13 December 2000, 26 and 27 December 2001, and 11 December 2002). Plots of corn, a summer crop in Uruguay, were planted on 17 October 1996, 5 October 1997, 23 October 1998, 7 October 1999, and 25 October 2001 and harvested on 3 April 1997, 12 March 1998, 7 April 1999, 1 April 2000, and 5 April 2002. Similarly, sunflower (a summer crop) plots were planted on 20 December 2000 and 30 December 2001 and harvested on 10 April 2001 and 24 April 2002. Pasture was sown on 12 June 2002. For analysis, residue was arbitrarily categorized into two categories by age: category 1 , residue 365 or fewer days old and category 2, residue 366 or more days old.

Plots were treated with the appropriate herbicides to control weeds. Soil samples (0 to $15 \mathrm{~cm}$ in depth) were collected from each plot prior to the planting of each crop and soil fertility was analyzed. Fertilizer was applied in accordance with standard agricultural practices in Uruguay (28).

Residue sampling and determination of residue decomposition and survival of G. zeae and other Fusarium spp. Residue was sampled every 3 months from Feb- 
ruary 2001 until March 2003 to estimate the amount of each type of residue on the soil surface and the colonization of residues by G. zeae. All visible residues at the soil surface were collected from five arbitrarily selected quadrats $(0.5$ by $0.5 \mathrm{~m})$ in each plot. The residue collected from each quadrat was air dried at 25 to $30^{\circ} \mathrm{C}$ for 24 h. Residue was separated visually by crop and then the weight of residue from each previous crop was determined. Samples were stored at $-10^{\circ} \mathrm{C}$ until processed.

Every 6 months from February 2001 until January 2003, Fusarium spp. other than G. zeae present on the collected residues were identified and the potential for inoculum production by $G$. zeae was assessed. Determination of $G$. zeae colonization was performed on 1.5- to 2-cm-long stem pieces, including a node in the case of gramineous species. A maximum of 30 pieces was assessed from each residue species per sample. However, where fewer than 30 pieces were recovered, all pieces recovered were assessed. Residue pieces were surface disinfected by being immersed in $0.5 \%$ sodium hypochlorite for $30 \mathrm{~s}$, immersed in $70 \%$ ethanol for $15 \mathrm{~s}$, rinsed three times in sterile deionized water, and blotted dry on sterile filter paper. Surface-disinfected residue pieces then were placed on pentachloronitrobenzene (PCNB) agar medium (15 $\mathrm{g}$ of peptone, 1 $\mathrm{g}$ of $\mathrm{KH}_{2} \mathrm{PO}_{4}, 0.5 \mathrm{~g}$ of $\mathrm{MgSO}_{4}, 1 \mathrm{~g}$ of Terrachlor [75\% $\mathrm{PCNB} \mathrm{wt} / \mathrm{wt}], 15 \mathrm{~g}$ of agar, $0.24 \mathrm{~g}$ of neomycin sulfate, and $1 \mathrm{~g}$ of streptomycin sulfate per liter of deionized water) (25) in 9-cm-diameter plastic petri dishes (10 nodes per plate, three plates per sample). Plated residue pieces then were incubated for 7 days at 20 to $22^{\circ} \mathrm{C}$ with 12 $\mathrm{h}$ light and dark cycles provided by a $1: 1$ combination of cool-white (F40/CW Worklite 25; Phillips, Sommerset, NJ) and blacklight (F40T12/BLB TL40W/08; Phillips) fluorescent lights. Colonies growing with salmon to pink-white mycelium were recorded as Fusarium spp. G. zeae colonies were estimated by transferring 10 arbitrarily selected colonies (50 colonies per treatment) identified as Fusarium spp. to carnation-leaf piece agar (CLA) medium (three to five sterile carnation leaf pieces [ 5 to $7 \mathrm{~mm}$ in diameter] per $2 \mathrm{ml}$ of $1.5 \%$ water agar) (14) and potato-dextrose agar (PDA). Cultures on CLA and PDA were incubated at 20 to $22^{\circ} \mathrm{C}$ with 12 -h light and dark cycles for 10 days. Bluish to black perithecia formation on CLA cultures confirmed the presence of $G$. zeae isolates. Fusarium colonies not forming perithecia were identified to species using the procedures outlined by Nelson et al. (27) and Burgess et al. (5).

Ascospore production. Ascospore production by $G$. zeae was determined on a known weight of residue that comprised node pieces for wheat, barley, corn, and gramineous weed residues, stem pieces for sunflower residue, and pieces of cobs for corn residue. Residue pieces were surface disinfested as described previously and placed on the surface of sterile sand (150 g) moistened with sterile deionized water ( $20 \mathrm{~g}$ ) within plastic boxes ( 200 by 300 by 70 mm, model Maxi N.1; Plasútil, Sâo Paulo, Brazil). To facilitate perithecia development, the boxes containing the residue pieces were incubated at 20 to $22^{\circ} \mathrm{C}$ under 12-h light and dark cycles for 21 days. Deionized water was added as needed based on the gross container weight to maintain moisture within the boxes. Following the incubation period, the residue pieces were placed in a solution of sterile deionized water and polyoxyethylene 20-sorbitan monolaurate (Tween 20; Fischer Scientific, Fair Lawn, $\mathrm{NJ})$. The dilution ratio used was $1 \mathrm{~g}$ of residue to $20 \mathrm{ml}$ of sterile water to $0.1 \mathrm{ml}$ of Tween 20. The residue pieces were left in solution for $12 \mathrm{~h}$ to allow ascospore discharge and then vigorously shaken for $10 \mathrm{~min}$. Three $1-\mathrm{ml}$ aliquots of the wash solution were obtained from each treatment and ascospore concentration was determined by counting ascospores in a known volume $(0.02 \mathrm{ml})$ of the suspension in each sample. Spores were counted under a compound microscope and expressed as the number of ascospores per gram of residue. The number of ascospores per square meter was calculated based on the number of ascospores produced per gram of residue and the amount of each residue type per square meter, expressed as a mean of five quadrats.

Disease incidence and severity. The incidence and severity of FHB in wheat and barley plots were assessed on wheat and barley plants at mid- to late-milk stage (Zadoks GS 75-77; 46) in 2001 and 2002. A hundred spikes were assessed in each plot, consisting of 10 primary heads at each of 10 arbitrarily selected sites within the center rows of each plot. FHB incidence was determined as the percentage of spikes with symptomatic spikelets. FHB severity was determined as the percentage of symptomatic spikelets in all 100 spikes. In both years, wheat cv. INIA Cabure, which is moderately resistant to moderately susceptible to FHB (6), was planted. Susceptible barley cv. Estanzuela Quebracho was planted in 2001 and moderately susceptible cv. INIA Ceibo was planted in 2002 (6).

Pathogenicity tests. Pathogenicity tests were conducted with 14 arbitrarily selected Fusarium isolates recovered from residues collected in either November 2002 or January 2003. The isolates comprised $F$. equiseti recovered from Digitaria sanguinalis collected in November 2001, F. sambucinum isolated from the 2001 barley residue, $F$. avenaceum recovered from the 2002 wheat residue, $F$. poae recovered from the 2002 barley residue, $F$. subglutinans from the 2001 corn residue, and $F$. solani from the 2001 sunflower residue. $F$. graminearum isolates recovered from the 2001 and 2002 wheat residue also were tested, as well as isolates from the 1999 and 2001 corn residues, the 2001 and 2002 barley residues, the 2001 sunflower residue, and D. sanguinalis collected in November 2002. Tests to determine the ability of isolates to induce disease in wheat and barley spikes were conducted in the greenhouse on plants of the susceptible wheat line LE 2294 and the susceptible barley cv. Estanzuela Quebracho. Seed were sown in plastic pots ( 150 by $150 \mathrm{~mm}$ in diameter by height) containing a 1:1:1 mixture of sand:soil:composted manure (Plantmax, Eucatex, Brazil). Four to five seeds were planted per pot and thinned to two plants when seedlings were at the three-leaf stage (Zadoks GS 13; 46). Plants were maintained at 20 to $25^{\circ} \mathrm{C}$ with alternating $12-\mathrm{h}$ light (high-pressure sodium SON lamps, 400W; Phillips, Belgium) and dark periods. Plants were fertilized every 2 weeks with soluble N-P-K (N-P-K 12-8-5 + micronutrients; ISUSA foliar fertilizer, San José, Uruguay) applied at $30 \mathrm{ml}$ per pot of a solution with a concentration of 0.4 liter/liter.

Monoconidial isolates were tested for pathogenicity. Conidial inoculum was produced on soybean medium (40 $\mathrm{g}$ of soybeans boiled in approximately $900 \mathrm{ml}$ of deionized water for $25 \mathrm{~min}$, filtered through two layers of cheesecloth, and adjusted to 1 liter with additional deionized water; and $15 \mathrm{~g}$ of agar) in petri plates incubated at 20 to $22^{\circ} \mathrm{C}$ with 12 -h light and dark cycles for 14 days. Conidia were harvested by adding 10 to $15 \mathrm{ml}$ of sterile distilled water to each plate and gently loosening spores with a sterile cover glass. Inoculum concentrations were adjusted to $5 \times 10^{4}$ conidia/ml. One to two spikes per pot (five pots per isolate per plant species) were inoculated at mid-anthesis (Zadoks GS 65; 46) with an airbrush (model VL3; Paasche Air Brush Company, Har Wood Heights, IL) operated at $0.84 \mathrm{~kg} \mathrm{~cm}^{-2}$. Wheat and barley plants sprayed with sterile deionized water were included as controls. Plants were incubated in a dew chamber at 20 to $22^{\circ} \mathrm{C}$ with a $12-\mathrm{h}$ photoperiod and $100 \%$ relative humidity for $72 \mathrm{~h}$. After incubation, plants were returned to the light and temperature conditions used prior to inoculation. Disease severity was evaluated 21 days after inoculation and expressed as the percentage of symptomatic spikelets per spike.

Statistical analyses. Survival of G. zeae and ascospore production did not meet assumptions of normality with binomial and Poisson distributions, respectively. Data were analyzed using generalized linear models (26) (SAS procedure GENMOD, version 8.1; SAS Institute Inc., Cary, NC). Tests of significance were based on likelihood ratio statistics.

Residue dry matter, FHB severity, FHB incidence, and pathogenicity data were 
subjected to analysis of variance using the GLM procedure of SAS (version 8.1; SAS Institute Inc.). Where the $F$ ratio was significant $(P<0.05)$, differences among treatment means were determined using protected least significant differences (LSD).

\section{RESULTS}

Average mean temperatures in 2001 during summer (January, February, March), autumn (April, May, June), winter (July, August, September), and spring (October, November, December) were 23, 14, 13, and $19^{\circ} \mathrm{C}$, respectively. In 2002, mean temperatures during these seasons were 27, 18,17 , and $25^{\circ} \mathrm{C}$, respectively. Average mean temperature during summer 2003 was $22^{\circ} \mathrm{C}$.

Total rainfall during 2001 was 1,513 $\mathrm{mm}$, with rainfall of $549 \mathrm{~mm}$ (30 rain events) in summer, $191 \mathrm{~mm} \mathrm{(23} \mathrm{rain}$ events) in fall, $230 \mathrm{~mm}$ ( 25 rain events) in winter, and $543 \mathrm{~mm}$ (36 rain events) in spring. In 2002, total rainfall was 1,222 $\mathrm{mm}$, with $360 \mathrm{~mm}$ (32 rain events) in summer, $291 \mathrm{~mm}$ (21 rain events) in fall, 212 $\mathrm{mm}$ (19 rain events) in winter, and 359 $\mathrm{mm}$ (26 rain events) in spring. Total rainfall in summer 2003 was $342 \mathrm{~mm}$ (23 rain events).
Residue decomposition. Significant reductions over time in the dry weight of residues were found in all treatments over the 25 months when samples were recovered (Table 1). No-till treatments had more residues compared with reduced-tillage treatments (Table 1). Significant differences were found for individual sampling dates between residue dry weight of no-till and reduced-tillage treatments, except for sampling dates when residue was sampled following harvest but before tillage operations were implemented (Table 1).

No-till corn produced more weight of residue than the other crops examined. Gramineous weeds generated less residue than the other residues recovered. The weights of both cereal and sunflower residues older than 1 year were significantly reduced compared with residues recovered when less than 1 year old (Table 1).

Survival of $G$. zeae on residues. $G$. zeae was isolated from all the recovered residues of gramineous species, regardless of treatment or sampling time. The relative level of $G$. zeae recovered from all cereal crop residues decreased with residue age (Fig. 1). G. zeae was isolated from corn residues up to 3 years after harvest, though residues were recovered until the fourth year after harvest. Based on the percentage of residue pieces colonized, wheat and barley residues had higher levels of $G$. zeae colonization than the residues of corn, gramineous weeds (D. sanguinalis, Cynodon dactylon, Lolium multiflorum, and Setaria spp.), fescue, or sunflower (Fig. 2). No colonization of forage legumes by $G$. zeae was detected.

Sunflower residue was found to be a substrate for the survival of G. zeae. Although $G$. zeae colonized sunflower residue, G. zeae was recovered at lower levels from this residue than from the cereal crop residues examined. Furthermore, G. zeae was recovered only from sunflower residues up to 1 year old (Fig. 1).

Barley and gramineous weed residues recovered from no-till plots were more highly colonized by $G$. zeae than residues recovered from reduced-tillage plots (Fig. 2 ). No significant differences were found among tillage treatments for the other residues examined, except at occasional sampling dates (i.e., corn residue in February 2001 and wheat residues in October 2001 and January 2003).

G. zeae was the Fusarium sp. recovered most frequently from wheat and barley residues sampled in the first 10 to 12

Table 1. Dry weight of seven types of residues (wheat, barley, corn, sunflower, fescue, forage legumes, and gramineous weeds) recovered from two tillage systems

\begin{tabular}{|c|c|c|c|c|c|c|c|c|c|c|c|}
\hline \multirow[b]{3}{*}{ System $^{y}$} & \multicolumn{11}{|c|}{ Dry weight $\left(\mathrm{g} / \mathrm{m}^{2}\right)$ on sampling date $\mathrm{d}^{\mathrm{x}}$} \\
\hline & \multicolumn{5}{|c|}{2001} & \multicolumn{5}{|c|}{2002} & \multirow[b]{2}{*}{$\operatorname{Mean}^{\mathrm{z}}$} \\
\hline & Feb & Apr & Jul & Oct & Dec & Mar & Aug & Nov & Jan & Mar & \\
\hline \multicolumn{12}{|l|}{ Wheat } \\
\hline NT1 & $350 \mathrm{~b}$ & $115 \mathrm{~b}$ & $105 \mathrm{c}$ & $41 \mathrm{~cd}$ & $146 \mathrm{~b}$ & $81 \mathrm{~b}$ & $35 \mathrm{de}$ & $19 \mathrm{~d}$ & $110 \mathrm{a}$ & $84 \mathrm{bc}$ & $121 \mathrm{~b}$ \\
\hline NT2 & $12 \mathrm{~d}$ & nrr & nrr & nrr & $56 \mathrm{~d}$ & $21 \mathrm{~d}$ & nrr & $\mathrm{nrr}$ & $3 \mathrm{~b}$ & nrr & 26 def \\
\hline RT1 & $372 a b$ & $26 \mathrm{~cd}$ & $6 \mathrm{ef}$ & $3 \mathrm{e}$ & $139 \mathrm{~b}$ & $21 \mathrm{de}$ & 9 ef & $34 \mathrm{~cd}$ & 136 a & $16 \mathrm{fg}$ & $84 \mathrm{c}$ \\
\hline RT2 & nrr & nrr & nrr & nrr & $12 \mathrm{e}$ & $18 \mathrm{de}$ & nrr & nrr & $6 \mathrm{~b}$ & nrr & $14 \mathrm{ef}$ \\
\hline \multicolumn{12}{|l|}{ Barley } \\
\hline NT1 & $400 \mathrm{a}$ & $181 \mathrm{a}$ & $117 \mathrm{bc}$ & $68 \mathrm{bc}$ & 238 a & $103 a b$ & $18 \mathrm{ef}$ & $8 \mathrm{~d}$ & $100 \mathrm{a}$ & $79 \mathrm{bc}$ & $131 \mathrm{~b}$ \\
\hline NT2 & nrr & nrr & nrr & nrr & $23 \mathrm{de}$ & nrr & $\mathrm{nrr}$ & nrr & nrr & $1 \mathrm{~g}$ & $12 \mathrm{ef}$ \\
\hline RT1 & $323 \mathrm{~b}$ & $43 \mathrm{c}$ & $18 \mathrm{de}$ & $5 \mathrm{e}$ & $113 \mathrm{c}$ & $48 \mathrm{c}$ & $6 \mathrm{~d}$ & nrr & $108 \mathrm{a}$ & 38 defg & $77 \mathrm{c}$ \\
\hline RT2 & nrr & nrr & nrr & nrr & nrr & nrr & nrr & nrr & nrr & nrr & $\ldots$ \\
\hline \multicolumn{12}{|l|}{ Corn } \\
\hline NT1 & $339 \mathrm{~b}$ & nrr & nrr & nrr & nrr & nrr & 176 a & $228 \mathrm{a}$ & $132 \mathrm{a}$ & $130 \mathrm{a}$ & $201 \mathrm{a}$ \\
\hline NT2 & $18 \mathrm{~d}$ & $42 c$ & $29 \mathrm{~d}$ & $6 \mathrm{e}$ & $7 \mathrm{e}$ & $5 \mathrm{de}$ & $3 \mathrm{f}$ & $1 \mathrm{~d}$ & nrr & nrr & $15 \mathrm{ef}$ \\
\hline RT1 & $174 \mathrm{c}$ & nrr & nrr & nrr & nrr & nrr & $118 \mathrm{~b}$ & $254 \mathrm{a}$ & $18 \mathrm{~b}$ & $15 \mathrm{fg}$ & $116 \mathrm{~b}$ \\
\hline RT2 & $4 d$ & $2 \mathrm{c}$ & 2 ef & $10 \mathrm{de}$ & $7 \mathrm{e}$ & nrr & $7 \mathrm{f}$ & nrr & nrr & $11 \mathrm{fg}$ & $5 \mathrm{f}$ \\
\hline \multicolumn{12}{|l|}{ Sunflower } \\
\hline NT1 & nrr & 167 a & $162 \mathrm{a}$ & $209 a$ & $166 \mathrm{~b}$ & $115 \mathrm{a}$ & $180 \mathrm{a}$ & $88 \mathrm{bc}$ & $24 \mathrm{~b}$ & 27 efg & $123 \mathrm{~b}$ \\
\hline NT2 & nrr & nrr & nrr & nrr & nrr & nrr & $63 \mathrm{~d}$ & $19 \mathrm{~d}$ & $8 \mathrm{~b}$ & $2 \mathrm{~g}$ & $23 \mathrm{def}$ \\
\hline RT1 & nrr & $183 \mathrm{a}$ & $133 \mathrm{~b}$ & $72 b$ & $48 \mathrm{~d}$ & $11 \mathrm{de}$ & $93 \mathrm{c}$ & $106 \mathrm{~b}$ & $17 \mathrm{~b}$ & 20 efg & $76 \mathrm{c}$ \\
\hline RT2 & nrr & nrr & nrr & nrr & nrr & nrr & $30 \mathrm{e}$ & $9 \mathrm{~d}$ & $4 \mathrm{~b}$ & $3 \mathrm{~g}$ & $11 \mathrm{ef}$ \\
\hline \multicolumn{12}{|l|}{ Fescue } \\
\hline NT & nrr & nrr & nrr & nrr & nrr & nrr & nrr & nrr & nrr & 40 cdef & $40 \mathrm{cdef}$ \\
\hline $\mathrm{RT}$ & nrr & nrr & nrr & nrr & nrr & nrr & nrr & nrr & nrr & 53 bcde & 53 cde \\
\hline \multicolumn{12}{|c|}{ Forage legumes } \\
\hline NT & nrr & nrr & nrr & nrr & nrr & nrr & nrr & nrr & nrr & $85 \mathrm{~b}$ & $85 \mathrm{bc}$ \\
\hline RT & nrr & nrr & nrr & nrr & nrr & nrr & nrr & nrr & nrr & $68 \mathrm{bcd}$ & $68 \mathrm{bc}$ \\
\hline \multicolumn{12}{|c|}{ Gramineous weeds } \\
\hline NT & $1 \mathrm{~d}$ & $17 \mathrm{~cd}$ & $1 \mathrm{f}$ & $1 \mathrm{e}$ & $20 \mathrm{e}$ & $14 \mathrm{de}$ & $1 \mathrm{f}$ & nrr & $2 \mathrm{~b}$ & $20 \mathrm{fg}$ & 8 ef \\
\hline $\mathrm{RT}$ & $1 \mathrm{~d}$ & nrr & nrr & $\mathrm{nrr}$ & $8 \mathrm{e}$ & $4 \mathrm{e}$ & nrr & nrr & $1 \mathrm{~b}$ & $14 \mathrm{fg}$ & $4 \mathrm{f}$ \\
\hline
\end{tabular}

${ }^{x}$ Values given are mean dry weight of all residue pieces sampled for a given treatment. Values with different letters in the same column are significantly different at $P=0.05$ according to least significant difference tests. Bold text indicates residue from recently harvested crops; nrr $=$ no residues recovered, either because residue was fully decomposed or because residues were not yet present in the cropping sequence.

y Tillage system and residue age. NT = no till and RT = reduced tillage. Residue was collected approximately every 3 months from February 2001 to March 2003 and divided according to age $(1=365$ or fewer days old and $2=$ older than 366 days $)$.

${ }^{\mathrm{z}}$ Mean of all sampling dates. 
months after harvest. Recovery of other species of Fusarium increased over time. $F$. equiseti, $F$. oxysporum, and $F$. solani were recovered in all five plant residues examined. $F$. avenaceum and $F$. sambucinum were recovered exclusively from wheat, barley, and gramineous weeds residues. F. acuminatum and $F$. poae were recovered from wheat, barley, gramineous weeds, and sunflower residues. F. tricinctum was recovered only from wheat and barley residues, while $F$. semitectum was recovered from barley and sunflower residues. F. subglutinans was recovered from the residues of barley, corn, and gramineous weeds. Other Fusarium spp. recovered included $F$. culmorum from wheat residues and $F$. verticillioides from corn residues.

Ascospore production. Wheat and barley residues produced more G. zeae ascospores per gram of residue, whereas gramineous weeds produced fewer asco- spores compared with the other residues examined (Table 2). Although the production of ascospores was at low levels, gramineous weeds supported year-round ascospore production. Even though $G$. zeae colonized sunflower residue, it did not produce ascospores on this substrate.

Inoculum production per unit area, calculated using ascospore production and residue coverage data, was greater in 1year-old and younger residues compared
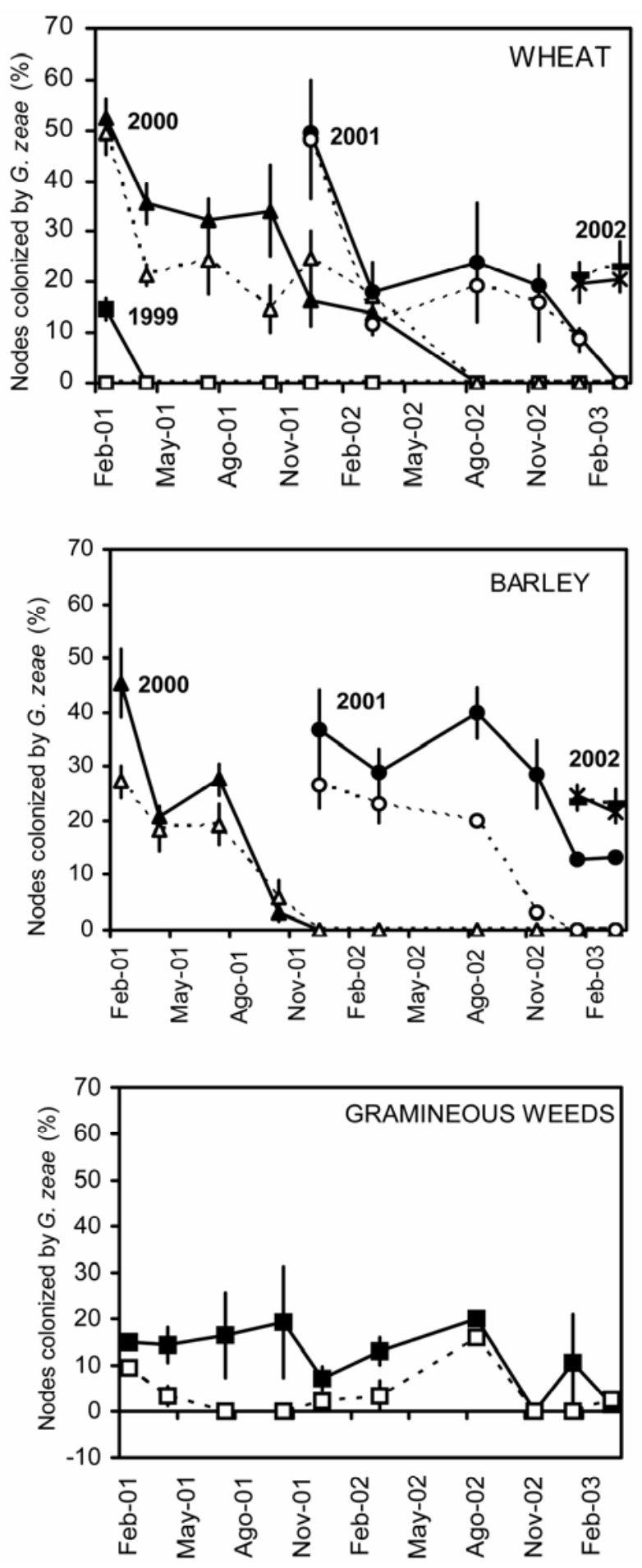
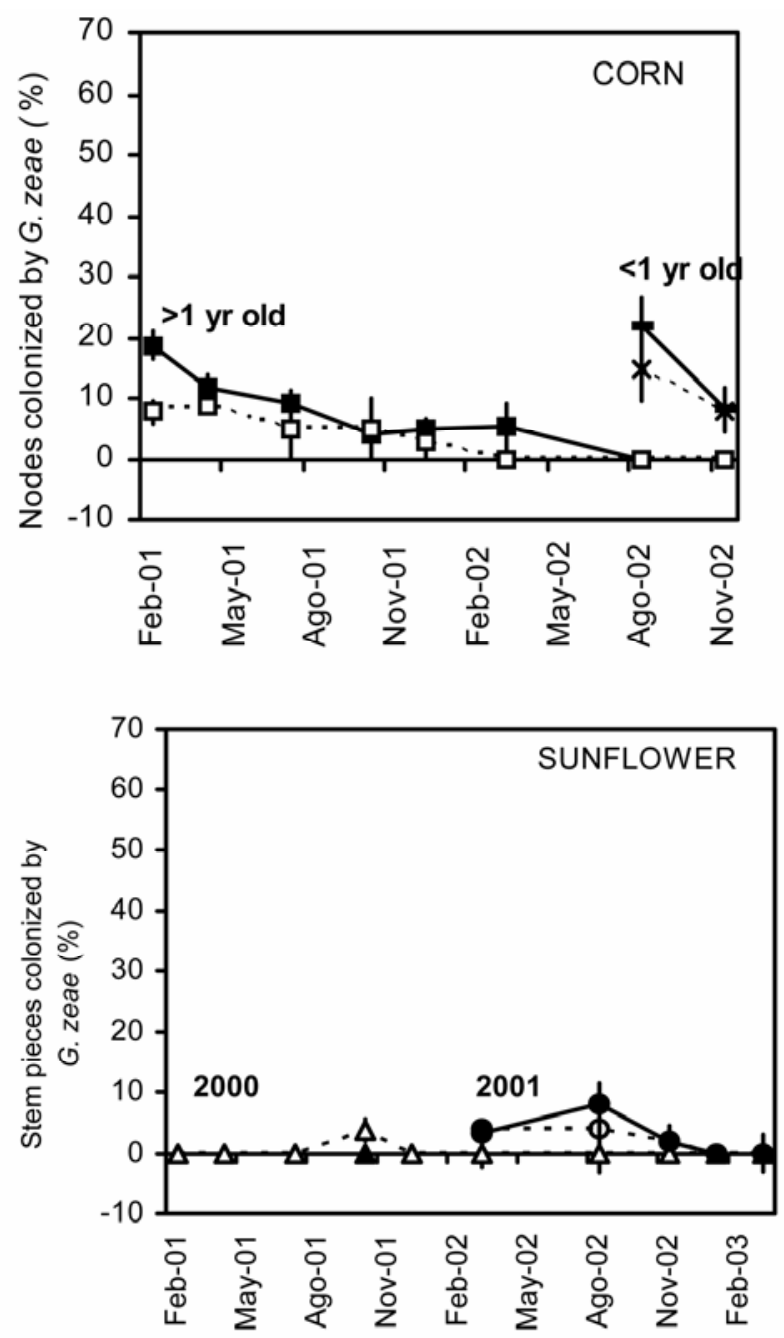

Fig. 1. Gibberella zeae colonization of five different residues (wheat, barley, corn, sunflower, and gramineous weeds [Digitaria sanguinalis, Cynodon dactylon, Lolium multiflorum, and Setaria spp.]) recovered from two tillage systems: no tillage (solid line) and reduced tillage (dashed line) in residues sampled from February 2001 to March 2003. Each point represents the mean percentage of all colonized residue sampled. Vertical bars represent standard errors. 
with older residues (Table 3 ). When comparisons were performed among cereal residues, winter cereal residues produced more ascospores per square meter $(2,442 \times$ $10^{3}$ ) over the entire sampling period than

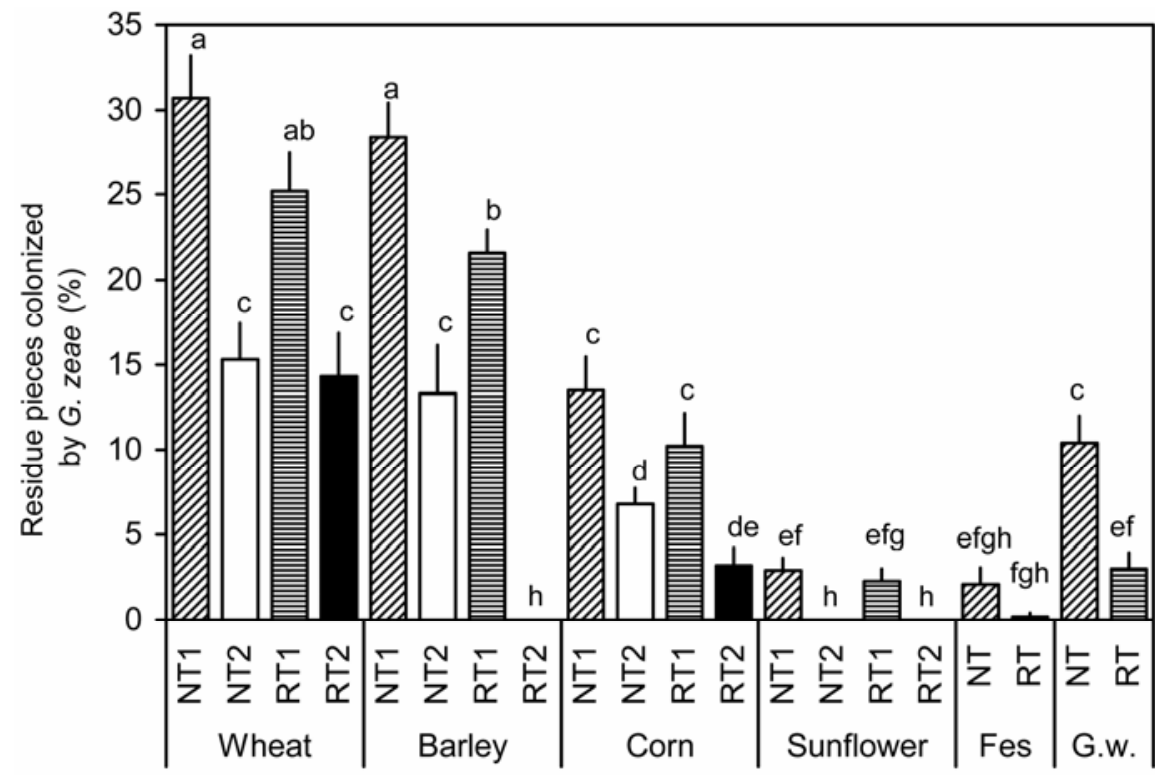

Fig. 2. Gibberella zeae colonization of six different residue types (wheat, barley, corn, sunflower, fescue [Fes; Festuca arundinacea], and gramineous weeds [G.w.; Digitaria sanguinalis, Cynodon dactylon, Lolium multiflorum, and Setaria spp.]) recovered from February 2001 to March 2003 from two tillage systems ( $\mathrm{NT}=$ no tillage and $\mathrm{RT}=$ reduced tillage). Residue was divided by age $(1=365$ or fewer days old and $2=$ older than 365 days). Values presented are the mean percentage of all colonized residue sampled. Values with different letters are significantly different at $P=0.05$ based on likelihood ratio statistics. Vertical bars represent standard errors.

Table 2. Ascospores of Gibberella zeae produced per gram of residue (wheat, barley, corn, sunflower, or gramineous weeds)

\begin{tabular}{|c|c|c|c|c|c|}
\hline \multirow[b]{3}{*}{ System $^{\mathrm{z}}$} & \multicolumn{5}{|c|}{ Gibberella zeae ascospores (ascospores per gram of residue) ${ }^{\mathrm{y}}$} \\
\hline & \multicolumn{3}{|c|}{2001} & \multirow[b]{2}{*}{ August 2002} & \multirow[b]{2}{*}{ January 2003} \\
\hline & February & July & December & & \\
\hline \multicolumn{6}{|l|}{ Wheat } \\
\hline NT1 & $14,267 \mathrm{a}$ & 4,667 a & $32,644 \mathrm{c}$ & $4,667 \mathrm{abc}$ & 14,933 a \\
\hline NT2 & $5,334 \mathrm{bcd}$ & nrr & $6,667 \mathrm{~d}$ & nrr & nra \\
\hline RT1 & $5,556 \mathrm{bc}$ & nra & 54,111 ab & $12,333 \mathrm{ab}$ & 13,600 a \\
\hline RT2 & nrr & nrr & $4,667 \mathrm{~d}$ & nrr & nra \\
\hline \multicolumn{6}{|l|}{ Barley } \\
\hline NT1 & $13,327 \mathrm{a}$ & $2,889 a b$ & 58,333 b & $14,333 \mathrm{a}$ & $\mathbf{8 , 4 0 0} \mathrm{b}$ \\
\hline NT2 & nrr & nrr & nra & nrr & nrr \\
\hline RT1 & $6,500 \mathrm{~b}$ & $2,500 \mathrm{~b}$ & 84,430 a & nra & 17,867 a \\
\hline RT2 & nrr & nrr & nrr & nrr & nrr \\
\hline \multicolumn{6}{|l|}{ Corn } \\
\hline NT1 & $7,467 \mathrm{~b}$ & nrr & nrr & $2,667 \mathrm{bc}$ & $5,067 \mathrm{~b}$ \\
\hline NT2 & $2,667 \mathrm{~cd}$ & $1,600 \mathrm{~b}$ & $16,000 \mathrm{~cd}$ & $1,000 \mathrm{c}$ & nrr \\
\hline RT1 & $1,667 \mathrm{~d}$ & nrr & nrr & $3,333 b c$ & $3,733 \mathrm{bc}$ \\
\hline RT2 & nra & nra & nra & nra & nrr \\
\hline \multicolumn{6}{|c|}{ Sunflower } \\
\hline NT1 & nrr & $0 \mathrm{c}$ & $0 \mathrm{e}$ & $0 \mathrm{~d}$ & $0 \mathrm{~d}$ \\
\hline NT2 & nrr & nrr & nrr & $0 \mathrm{~d}$ & $0 \mathrm{~d}$ \\
\hline RT1 & nrr & $0 \mathrm{c}$ & $0 \mathrm{e}$ & $0 \mathrm{~d}$ & $0 \mathrm{~d}$ \\
\hline RT2 & nrr & nrr & nrr & $0 \mathrm{~d}$ & $0 \mathrm{~d}$ \\
\hline \multicolumn{6}{|c|}{ Gramineous weeds } \\
\hline NT & $2,500 \mathrm{~cd}$ & nra & $4,000 \mathrm{~d}$ & $2,667 b c$ & $1,867 \mathrm{c}$ \\
\hline RT & $2,667 \mathrm{~cd}$ & nrr & nra & nrr & nra \\
\hline
\end{tabular}

${ }^{\mathrm{y}}$ Values with different letters in the same column are significantly different at $P=0.05$ based on likelihood ratio statistics. Bold text indicates residue from recently harvested crops, nra $=$ no residue available for analysis of ascospore production after the analysis of dry weight was completed, and nrr $=$ no residue recovered.

${ }^{\mathrm{z}}$ Tillage system and age group of residue. Residues were collected from two tillage systems (NT = no till and RT $=$ reduced tillage) from February 2001 to March 2003 and divided into two age groups (1 $=365$ or fewer days old and $2=$ older than 366 days). area between winter cereal residues and corn residues (Table 3 ). When sampling for residue was carried out immediately after winter cereal harvest and prior to tillage operations (December, January, or February), there were no significant differences in the number of ascospores produced per square meter between no-till and reduced-tillage treatments.

Disease incidence and severity. In wheat, the incidence of FHB was higher in 2001 than 2002. In 2002, no-till wheat had higher FHB incidence than wheat under reduced tillage. The incidence of FHB in barley in both 2001 and 2002 was over $94 \%$, and no significant effects of tillage treatment were observed. The incidence of FHB in wheat and barley was influenced by year (Table 4 ).

Disease severity also was greater in both wheat and barley in 2001 than in 2002 (Table 4). Although FHB was less severe in 2002, the severity in no-till plots was greater than in the reduced-tillage treatments in both crops. In both 2001 and 2002, the severity of FHB was greater in barley than wheat (Table 4).

Pathogenicity tests. All isolates tested caused symptoms of FHB on wheat and barley spikes, except when wheat was inoculated with $F$. subglutinans (Table 5). In both wheat and barley, the effect of the isolate on FHB severity was significant. Spikes, mock-inoculated with sterile water to serve as a control treatment, did not show any symptoms of FHB. The mean FHB severity of all isolates tested was lower in wheat than the mean FHB severity for inoculated barley plants (Table 5).

The G. zeae isolates from 2002 wheat residue produced the greatest disease severity on both wheat and barley plants. On wheat plants, G. zeae isolates caused significantly greater disease severity compared with all other isolates tested except the $F$. avenaceum isolate. In barley, the isolate of G. zeae from 2002 wheat residue also caused the highest FHB severity of the isolates tested, but not significantly more than the isolate of G. zeae from 2002 barley residue or the $F$. equiseti and $F$. sambucinum isolates tested.

\section{DISCUSSION}

Results from this study show that $G$. zeae can survive and produce inoculum on wheat, barley, corn, and gramineous pasture or weed species, indicating that multiple residue types can be long-term sources of G. zeae inoculum. These findings agree with earlier studies in other wheat and barley production areas (11-13,36,40).

Our findings suggest that birdsfoot trefoil and white clover, which are common components of perennial pastures in Uruguay, do not appear to support G. zeae or contribute to inoculum. Fernandez (12) was unable to recover $G$. zeae from naturally infected fields of birdsfoot trefoil, only recovering the fungus from artificially 
inoculated plants. Other legumes commonly found in perennial pastures in Uruguay, such as alfalfa (Medicago sativa L.) and red clover ( $T$. pratense L.), have been cited as hosts of $G$. zeae $(12,43)$ but were not evaluated in this study.

Sunflower residue was able to support low levels of G. zeae colonization; however, the production of perithecia was not observed on this substrate. To our knowledge, this is the first report indicating that sunflower residue is colonized by G. zeae. However, G. zeae has been reported as part of the mycoflora present in sunflower florets (37). The fact that no perithecia production was observed in this residue might indicate that the conditions in this study were not optimal or that the biochemical composition of the residue did not support perithecia production.

Gramineous species that flower during summer, whether components of pastures (fescue) or weeds (D. sanguinalis, $C$. dactylon, and Setaria spp.), could contribute ascospore inoculum in Uruguayan no-till production systems during the winter and early spring when wheat flowering and barley heading occur. Even though fescue was not evaluated for perithecia or ascospore production during the course of this study, fescue has been observed to support perithecial production after ripening (31) and, therefore, also may contribute to the inoculum pressure in growers' fields during spring.

Corn residue was colonized at lower levels compared with winter cereal residues, yet the residue supported $G$. zeae for longer periods of time as a consequence of the slower decomposition of corn residue. Ascospore production per unit area in corn was lower than for wheat and barley residues over the entire sampling period. Corn is used mostly in rotations in dairy production systems in the southern part of southwestern Uruguay. Although corn is planted in rotation with wheat and pastures on these farms, it generally is used for silage and, consequently, much smaller amounts of residue are left in the field compared with field plots examined in this study. The low levels of ascospore production and limited residues left in fields indicate that the contribution of corn to G. zeae inoculum in Uruguayan production systems is probably low, in contrast to many parts of North America and Europe where corn is frequently cited as being a major factor contributing to FHB epidemics $(10,19,38$, 39,41).

The decline in the colonization of residues by $G$. zeae and inoculum production over the 2 years of this study parallel residue decomposition and was expected based on previous studies examining $G$. zeae-infested wheat $(18,32,45)$ and corn (18) residues over time. In this study, wheat and barley residues decomposed faster than corn residues, especially in the first few months after harvest. The rate of residue decomposition depends on many factors, including the biochemical form of the residue and the suitability of the environment and the availability of nutrients, especially nitrogen, for the microbes involved in decomposition. The rapid decomposition of the wheat and barley might be due to the fact that the subsequent summer crops provided an environment that promoted microbial activity by increasing the moisture present in residues for long periods. The warm, moist conditions below

the canopy of summer crops, as well as reduced light, also might be detrimental to the production of perithecia by G. zeae. Corn residue decomposed more slowly than winter cereals, largely because low temperatures prevail after the harvesting of corn in April, whereas warmer temperatures follow the harvest of winter cereals in November to December. Different patterns of inoculum production in the different plant residues over time also might have reflected the differential nutritional status

Table 3. Number of ascospores $\left(\times 10^{3}\right)$ of Gibberella zeae produced per square meter on wheat, barley, corn, sunflower, and gramineous weeds residues from two tillage systems

\begin{tabular}{|c|c|c|c|c|c|}
\hline \multirow[b]{3}{*}{ System $^{z}$} & \multicolumn{5}{|c|}{ G. zeae ascospores (ascospores per square meter of residue) } \\
\hline & \multicolumn{3}{|c|}{2001} & \multirow[b]{2}{*}{ August 2002} & \multirow[b]{2}{*}{ January 200} \\
\hline & February & July & December & & \\
\hline \multicolumn{6}{|l|}{ Wheat } \\
\hline NT1 & $4,907 \mathrm{ab}$ & $486 \mathrm{a}$ & $3,570 \mathrm{~b}$ & $163 \mathrm{ab}$ & 1,639 a \\
\hline NT2 & $162 \mathrm{~d}$ & nrr & $369 \mathrm{c}$ & nrr & nra \\
\hline RT1 & $2,074 \mathrm{~b}$ & nra & $8,238 \mathrm{ab}$ & $113 \mathrm{~b}$ & 1,844 a \\
\hline RT2 & nrr & nrr & $52 \mathrm{~d}$ & nrr & nra \\
\hline \multicolumn{6}{|l|}{ Barley } \\
\hline NT1 & $5,397 \mathrm{a}$ & $400 \mathrm{a}$ & $13,871 \mathrm{a}$ & $264 a b$ & $773 \mathrm{~b}$ \\
\hline NT2 & nrr & nrr & nrr & nrr & nrr \\
\hline RT1 & $2,098 \mathrm{~b}$ & $43 \mathrm{~b}$ & $9,331 \mathrm{ab}$ & nra & $1,928 \mathrm{a}$ \\
\hline RT2 & nrr & nrr & nrr & nrr & nrr \\
\hline \multicolumn{6}{|l|}{ Corn } \\
\hline NT1 & $2,221 \mathrm{ab}$ & nrr & $\mathrm{nrr}$ & $482 \mathrm{a}$ & $667 \mathrm{~b}$ \\
\hline NT2 & $50 \mathrm{~d}$ & $48 \mathrm{~b}$ & $462 \mathrm{c}$ & $3 c$ & nrr \\
\hline RT1 & $287 \mathrm{~cd}$ & nrr & nrr & 393 a & $66 \mathrm{c}$ \\
\hline RT2 & nra & nra & nra & nra & nrr \\
\hline \multicolumn{6}{|c|}{ Sunflower } \\
\hline NT1 & $\mathrm{nrr}$ & $0 \mathrm{c}$ & $0 \mathrm{e}$ & $0 \mathrm{~d}$ & $0 \mathrm{e}$ \\
\hline NT2 & $\mathrm{nrr}$ & nrr & nrr & $0 \mathrm{~d}$ & $0 \mathrm{e}$ \\
\hline RT1 & $\mathrm{nrr}$ & $0 \mathrm{c}$ & $0 \mathrm{e}$ & $0 \mathrm{~d}$ & $0 \mathrm{e}$ \\
\hline RT2 & $\mathrm{nrr}$ & nrr & $\mathrm{nrr}$ & $0 \mathrm{~d}$ & $0 \mathrm{e}$ \\
\hline \multicolumn{6}{|c|}{ Gramineous weeds } \\
\hline NT & $2 \mathrm{e}$ & nra & $58 \mathrm{~d}$ & $2 \mathrm{c}$ & $3 \mathrm{~d}$ \\
\hline RT & $3 \mathrm{e}$ & nrr & nra & nrr & nra \\
\hline
\end{tabular}

y Values with different letters in the same column are significantly different at $P=0.05$ based on likelihood ratio statistics; nra $=$ no residue available for analysis of ascospore production after the analysis of dry weight was completed and nrr $=$ no residue recovered.

${ }^{\mathrm{z}}$ Tillage system and age group of residue. $\mathrm{NT}=$ no tillage and $\mathrm{RT}=$ reduced tillage. Residue was collected from February 2001 to March 2003 and divided into two age groups $(1=365$ or fewer days old and $2=$ older than 366 days).

Table 4. Fusarium head blight (FHB) incidence (\%) and severity (\%) in wheat and barley in 2001 and 2002 for two tillage treatments $(\mathrm{NT}=\text { no tillage and } \mathrm{RT}=\text { reduced tillage })^{\mathrm{z}}$

\begin{tabular}{lcccc}
\hline & & \multicolumn{2}{c}{ Year } & \\
\cline { 3 - 4 } Crop & Treatment & $\mathbf{2 0 0 1}$ & $\mathbf{2 0 0 2}$ & Mean \\
\hline FHB incidence & & & & \\
Wheat & $\mathrm{NT}$ & $93 \mathrm{a}$ & $64 \mathrm{a}$ & $79 \mathrm{c}$ \\
& $\mathrm{RT}$ & $91 \mathrm{a}$ & $32 \mathrm{~b}$ & $62 \mathrm{~d}$ \\
Mean & $\ldots$ & $92 \mathrm{C}$ & $48 \mathrm{D}$ & $\ldots$ \\
Barley & $\mathrm{NT}$ & $100 \mathrm{e}$ & $94 \mathrm{f}$ & $97 \mathrm{~g}$ \\
& $\mathrm{RT}$ & $100 \mathrm{e}$ & $96 \mathrm{f}$ & $98 \mathrm{~h}$ \\
Mean & $\ldots$ & $100 \mathrm{G}$ & $95 \mathrm{H}$ & $\ldots$ \\
FHB severity & & & & \\
Wheat & $\mathrm{NT}$ & $19.6 \mathrm{j}$ & $9.0 \mathrm{j}$ & $14.3 \mathrm{~m}$ \\
& $\mathrm{RT}$ & $18.4 \mathrm{j}$ & $4.5 \mathrm{k}$ & $9.9 \mathrm{n}$ \\
Mean & $\ldots$ & $19.0 \mathrm{M}$ & $6.8 \mathrm{~N}$ & $\ldots$ \\
Barley & $\mathrm{NT}$ & $54.8 \mathrm{p}$ & $21.9 \mathrm{q}$ & $38.4 \mathrm{~s}$ \\
& $\mathrm{RT}$ & $51.6 \mathrm{p}$ & $18.2 \mathrm{r}$ & $34.9 \mathrm{t}$ \\
Mean & $\ldots$ & $53.2 \mathrm{~S}$ & $20.1 \mathrm{~T}$ & $\ldots$ \\
\hline
\end{tabular}

${ }^{z}$ Values given are the mean of five replicates. Values in a column, for either incidence or severity in either wheat or barley, followed by different lowercase letters are significantly different at $P=0.05$ according to least significant difference (LSD) tests. Values in a row followed by different uppercase letters are significantly different at $P=0.05$ according to LSD tests. 
of each substrate, as suggested by Khonga and Sutton (18).

The rate of residue decomposition is inversely related to the amount of residue left on the soil surface $(18,32)$. Contact of residue with soils, and especially the burial of residue, promotes greater microbial activity, accelerating decomposition (29). Residues in no-till systems decompose more slowly than residues under reducedtillage systems; thus, residues in no-till systems likely would support the survival of $G$. zeae and inoculum production for longer periods of time.

When evaluating the effect of tillage systems on the incidence and severity of FHB in wheat and barley, we observed that disease development is highly dependent on climate. In years with extremely conducive climatic conditions from flowering to harvest for wheat and from heading to harvest for barley, such as occurred in 2001, tillage systems did not have a significant effect on FHB. In years with only moderately conducive conditions for FHB (i.e., La Estanzuela 2002), the impact of tillage on FHB development was apparent. Above-average rainfall, both amount and frequency, during spring 2001 undoubtedly contributed to the severe outbreak of FHB in commercial wheat and barley crops in Uruguay. Previous studies also suggest that weather conditions are more influential than tillage practices per se on the development of FHB $(7,10,24)$.

G. zeae was the Fusarium sp. most frequently recovered from winter cereal residues in the first few months following harvest. G. zeae probably benefits in competition with other saprophytes from its ability to colonize wheat and barley residues as a parasite. Other Fusarium spp. known to have greater competitive saprophytic abilities in wheat or barley residues (i.e., F. avenaceum and F. poae) or in soil (i.e., F. oxysporum) increased in prevalence as $G$. zeae populations decreased over time. These results support the findings from our previous study conducted in the Upper Midwest of the United States (32). In this study, species other than $G$. zeae dominated the Fusarium populations in nonwinter cereal residues. The most common species recovered were $F$. verticillioides in corn residues, $F$. equiseti in gramineous weeds residues, and $F$ oxysporum and $F$. solani in sunflower residues. F. verticillioides is known as a common pathogen of corn (42), while both $F$. oxysporum and $F$. solani have been reported as pathogens of sunflower (34). The dominance of pathogenic species in the residue of host plants supports the theory that species gain a competitive advantage as a saprophyte by establishing themselves as pathogens in host tissue (4).

The results of this study also confirm that isolates of $G$. zeae, regardless of the plant residue from which they were recovered, are capable of infecting wheat and barley plants. However, the aggressiveness of Fusarium isolates, as indicated by the relative severity of FHB in inoculated wheat and barley plants both within and among species, varies considerably. These findings are in agreement with recent studies examining the relative aggressiveness of Fusarium isolates (R. Dill-Macky, unpublished data).

Based on the information generated in this study, we conclude that, under the mixed production systems of southwestern Uruguay, wheat and barley appear to be the most important species contributing to G. zeae inoculum. These residues should be avoided if wheat or barley would be planted, particularly under no-tillage systems. Priority should be given to planting wheat or barley in forage legume, sunflower, or perennial pasture residues. Even

Table 5. Fusarium head blight (FHB) severity 21 days after inoculation of wheat and barley plants with 14 isolates representing seven Fusarium spp. recovered from five crop residues collected between 1999 and 2002

\begin{tabular}{llccccc}
\hline & \multicolumn{2}{c}{ Isolates recovered from } & & \multicolumn{2}{c}{ FHB severity $(\%)^{\mathbf{z}}$} \\
\cline { 2 - 3 } \cline { 5 - 6 } Fusarium sp. & \multicolumn{2}{c}{ Residue type } & Year & & Wheat & Barley \\
\hline Fusarium graminearum & Wheat & 2002 & & $18.0 \mathrm{a}$ & $19.0 \mathrm{a}$ \\
F. graminearum & Wheat & 2001 & & $8.2 \mathrm{~b}$ & $4.3 \mathrm{~cd}$ \\
F. graminearum & Sunflower & 2001 & & $2.1 \mathrm{~b}$ & $9.2 \mathrm{bcd}$ \\
F. graminearum & Corn & 2001 & & $2.3 \mathrm{~b}$ & $9.2 \mathrm{bcd}$ \\
F. graminearum & Corn & 1999 & & $2.9 \mathrm{~b}$ & $1.2 \mathrm{~d}$ \\
F. graminearum & Barley & 2002 & & $2.9 \mathrm{~b}$ & $16.5 \mathrm{ab}$ \\
F. graminearum & Barley & 2001 & & $3.7 \mathrm{~b}$ & $2.2 \mathrm{~d}$ \\
F. graminearum & Digitaria sanguinalis & $\ldots$ & & $2.3 \mathrm{~b}$ & $3.4 \mathrm{~cd}$ \\
F. equiseti & D. sanguinalis & $\ldots$ & & $5.1 \mathrm{~b}$ & $16.4 \mathrm{ab}$ \\
F. sambucinum & Barley & 2001 & & $0.6 \mathrm{~b}$ & $12.5 \mathrm{abc}$ \\
F. avenaceum & Wheat & 2002 & & $9.8 \mathrm{ab}$ & $6.4 \mathrm{~cd}$ \\
F. poae & Barley & 2002 & & $5.4 \mathrm{~b}$ & $5.3 \mathrm{~cd}$ \\
F. subglutinans & Corn & 2001 & & $0 \mathrm{~b}$ & $3.2 \mathrm{~cd}$ \\
F. solani & Sunflower & 2001 & & $2.7 \mathrm{~b}$ & $2.0 \mathrm{~d}$ \\
Mean FHB severity & (\%) & .. & $\ldots$ & & $4.7 \mathrm{~B}$ & $7.9 \mathrm{~A}$ \\
\hline
\end{tabular}

$\overline{\mathrm{z}}$ Values given are the mean of 10 replicates. Values in a column followed by different lowercase letters are significantly different at $P=0.05$ according to least significant difference LSD tests. Values in a row followed by different uppercase letters are significantly different at $P=0.05$ according to LSD test.

when these last two options allow for the survival of $G$. zeae from one season to the next, they produce no primary inoculum (sunflower residue) or very low levels of inoculum (pasture).

Management of FHB is likely to involve a combination of resistance, use of fungicides, and cultural practices aimed at reducing the primary inoculum in wheat and barley crops. Practices such as tillage, residue management, and crop sequence play significant roles in determining the risk of FHB.

\section{ACKNOWLEDGMENTS}

We thank J. Sawchik (INIA) and M. Mohan Kohli (CIMMYT) for providing the field trial and partial funding, respectively; and M. García, W. Alvarez, and A. Hernández for their assistance.

\section{LITERATURE CITED}

1. Baird, R. E., Mullinix, B. G., Peery, A. B., and Lang, M. L. 1997. Diversity and longevity of the soybean debris mycobiota in a no-tillage system. Plant Dis. 81:530-534.

2. Boasso, C. 1961. Estado fitosanitario de los cultivos de trigo de la reciente cosecha [Phytosanitary state of wheat crops in present growing season]. Bol. Inf. 854:7.

3. Boerger, A. 1928. Observaciones sobre agricultura, quince años de trabajos fitotécnicos en Uruguay [Agricultural notes: fifteen years of crop breeding in Uruguay]. Montevideo, Uruguay.

4. Bruehl, G. W., and Lai, P. 1966. Prior-colonization as a factor in the saprophytic survival of several fungi in wheat straw. Phytopathology 56:766-768.

5. Burgess, L. W., Summerell, B. A., Bullock, S., Gott, K. P., and Backhouse, D. 1994. Laboratory Manual for Fusarium Research. Third ed. University of Sydney, Sydney, Australia.

6. Castro, M., Pereyra, S., Germán, S., and Vázquez, D. 2004. Resultados experimentales de evaluación de trigos y cebadas cerveceras de los 3 últimos años para el registro nacional de cultivares. Período 2003. INASE-INIA.

7. Champeil, A., Fourbet, J. F., Dore, T., and Rossignol, L. 2004. Influence of cropping system on Fusarium head blight and mycotoxin levels in winter wheat. Crop Prot. 23:531-537.

8. da Costa Neto, J. P. 1976. Lista de fungos sobre gramíneas (capins e cereais) no Rio Grande do Sul [List of fungi on gramineous species in Rio Grande do Sul, Brazil]. Rev. Facul. Agron. UFRGS 1:43-78.

9. Díaz de Ackermann, M., and Kohli, M. M. 1997. Research on Fusarium head blight of wheat in Uruguay. Pages 13-18 in: Fusarium Head Scab: Global Status and Prospects. H. J. Dubin, L. Gilchrist, J. Reeves, and A. McNab, eds. CIMMYT, DF, Mexico.

10. Dill-Macky, R., and Jones, R. 2000. The effect of previous crop residues and tillage on Fusarium head blight of wheat. Plant Dis. 84:654660.

11. Farr, D. F., Bills, G. F., Chamuris, G. P., and Rossman, A. Y. 1989. Fungi on Plants and Plant Products in the United States. The American Phytopathological Society Press, St. Paul, $\mathrm{MN}$.

12. Fernandez, M. R. 1991. Recovery of Cochliobolus sativus and Fusarium graminearum from living and dead wheat and nongramineous winter crops in southern Brazil. Can. J. Bot. 69:1900-1906.

13. Fernandez, M. R., and Fernandes, J. M. C. 1990. Survival of wheat pathogens in wheat and soybean crop residues in southern and central Brazil. Can. J. Plant Pathol. 12:289294. 
14. Fischer, N. L., Burgess, L. W., Tousson, T. A., and Nelson, P. E. 1982. Carnation leaves as a substrate for preserving cultures of Fusarium species. Phytopathology 72:151-153.

15. Gilbert, J., Fernando, W. G. D., Ahmed, H. U., and Brule-Babel, A. 2004. The role of crop stubble in production of inoculum of Fusarium graminearum. Page 452 in: Proc. 2nd Int. Symp. Fusarium Head Blight. S. M. Canty, T. Boring, J. Wardwell, and R. W. Ward, eds. Michigan State University, East Lansing.

16. Hoffer, G. N., Johnson, A. G., and Atanasoff, D. 1918. Corn-rootrot and wheatscab. J Agric. Res. 3:611-612.

17. Holbert, J. R., Trost, J. F., and Atanasoff, D. 1919. Wheat scabs as affected by systems of rotation. Phytopathology 9:45-47.

18. Khonga, E. B., and Sutton, J. C. 1988. Inoculum production and survival of Gibberella zeae in maize and wheat residues. Can. J. Plant Pathol. 10:232-239.

19. Krebs, H., Dubois, D., Kulling, C., and Forrer, H. R. 2000. Fusarien- und Toxinbelastung des Weizens dei Direktsaat [The effects of preceding crop and tillage on the incidence of Fusarium spp. and toxin content in winter wheat grain]. Agrarforschung 7:264-268

20. Markell, S. G., and Francl, L. J. 2003. Fusarium head blight inoculum: species prevalence and Gibberella zeae spore type. Plant Dis. 87:814-820.

21. Martino, D. L. 1997. Siembra directa en sistemas agrícola-ganaderos del litoral. Serie Técnica 82. INIA, Colonia, Uruguay.

22. Mathre, D. E. 1997. Compendium of Barley Diseases. Second ed. The American Phytopathological Society Press, St. Paul, MN.

23. MGAP-DIEA, 2000. Anuario Estadísticas Agropecuarias 2000 [Annual report on agricultural statistics 2000]. Ministerio de Ganadería Agricultura y Pesca, Montevideo, Uruguay.

24. Miller, J. D., Culley, J., Fraser, K., Hubbard, S., Meloche, F., Ouellet, T., Seaman, W. L., Seifert, K. A., Turkington, K., and Voldeng, H. 1998. Effect of tillage practice on Fusarium head blight of wheat. Can. J. Plant Pathol. 20:95-103.

25. Nash, S. M., and Snyder, W. C. 1962. Quantitative estimations by plate counts of propa- gules of the bean root rot Fusarium in field soils. Phytopathology 52:567-572.

26. Nelder, J. A., and Wedderburn, R. W. M. 1972. Generalized Linear Models. Chapman and Hall, London.

27. Nelson, P. A., Tousson, T. A., and Marasas, W. F. O. 1983. Fusarium species: An Illustrated Manual for Identification. The Pennsylvania State University Press, University Park.

28. Oudri, N., Castro, J. L., Doti, R., and Secondi de Carbonell, A. 1976. Guía para la fertilización de cultivos [Crop fertilization guide]. CIAAB, Dirección de Suelos y Fertilizantes, MAP.

29. Parr, J. F., and Papendick, R. I. 1978. Factors affecting the decomposition of crop residues by microorganisms. Pages 101-129 in: Crop Residue Management Systems. W. R. Oschwald, ed. ASA Spec. Publ. 31. The American Society of Agronomy, Madison, WI.

30. Perea, C., and Díaz, M. 1980. Relevamiento de enfermedades de trigo en el Uruguay 19681979 [Wheat diseases survey in Uruguay 1968-1979]. Invest. Agron. 2:42-51.

31. Pereyra, S., and Díaz de Ackermann, M. 2003. Manejo de la fusariosis de la espiga [Fusarium head blight management]. Pages 1-15. in: 5ta Jornada Nacional de Manejo y Calidad del Trigo. Mesa del Trigo, Mercedes, Uruguay.

32. Pereyra, S. A., Dill-Macky, R., and Sims, A. L. 2004. Survival and inoculum production of Gibberella zeae in wheat residue. Plant Dis. 88:724-730.

33. Pereyra, S., and Stewart, S. 2001. Investigación en fusariosis de la espiga de cebada en Uruguay [Research on Fusarium head blight of barley in Uruguay]. Pages 41-68. in: XXI Reunião Anual de Pesquisa de cevada Anais e ata. E. Minella, ed. EMBRAPA Trigo, Passo Fundo, Brazil.

34. Pineda, J. B., Colmenares, O., and Avila, J. 1991. Evaluación de semilla híbrida de girasol Helianthus annus L. en relación con la incidencia de enfermedades [Pathogens incidence on hybrid sunflower Helianthus annus L. seeds]. Agron. Trop. 41:205-214.

35. Pritsch, C. 1995. Variabilidad patogénica en Fusarium spp. agente causal del golpe blanco del trigo [Pathogenic variability of Fusarium spp. causal agent of wheat scab]. FPTA-INIA. Informe final.

36. Reis, E. M. 1988. Doenças do trigo III Giberela [Wheat diseases III. Fusarium head blight]. Segunda ediçao, Sao Paulo, Brazil.

37. Rodriguez, M. A., Venedikian, N., and Godeas, A. 2001. Fungal populations on sunflower (Helianthus annus) anthosphere and their relation to susceptibility to Sclerotinia sclerotiorum attack. Mycopathologia 150:143-150.

38. Schaafsma, A. H., Tamburic-Illincic, L. Miller, J. D., and Hooker, D. C. 2001. Agronomic considerations for reducing deoxynivalenol in wheat grain. Can. J. Plant Pathol. 23:279-285.

39. Shaner, G. 2003. Epidemiology of Fusarium head blight of small grain cereals in North America. Pages 84-119 in: Fusarium Head Blight of Wheat and Barley. K. Leonard and W. Bushnell, eds. The American Phytopathological Society Press, St. Paul, MN

40. Sutton, J. C. 1982. Epidemiology of wheat head blight and maize ear rot caused by Fusarium graminearum. Can. J. Plant Pathol. 4:195-209.

41. Teich, A. H., and Hamilton, J. R. 1985. Effect of cultural practices, soil phosphorus, potassium, and $\mathrm{pH}$ on the incidence of Fusarium head blight and deoxynivalenol levels in wheat. Appl. Environ. Microbiol. 49:1429-1431.

42. White, D. G. 1999. Compendium of Corn Diseases. Third ed. The American Phytopathological Society Press, St. Paul, MN.

43. Wiese, M. V. 1987. Compendium of Wheat Diseases. Second ed. The American Phytopathological Society Press, St. Paul, MN

44. Windels, C. E., and Komedahl, T. 1984. Lateseason colonization and survival of Fusarium graminearum group II in cornstalks in Minnesota. Plant Dis. 68:791-793.

45. Yi, C., Kaul, H.P., Kubler, E., and Aufhammer, W. 2002. Populations of Fusarium graminearum on crop residues as affected by incorporation depth, nitrogen and fungicide application. Z. Pflanzenkrankh. Pflanzenschutz [J. Plant Dis. Prot.] 109:252-263.

46. Zadoks, J. C., Chang, T. T., and Konzac, C. F. 1974. A decimal code for the growth stages of cereals. Weed Res. 14:415-421. 